\title{
Effect of Dietary Starch or Micro Algae Supplementation on Rumen Fermentation and Milk Fatty Acid Composition of Dairy Cows
}

\author{
C. Boeckaert, ${ }^{\star 1}$ B. Vlaeminck, ${ }^{\star 1}$ J. Dijkstra,† A. Issa-Zacharia, ${ }^{\star}$ T. Van Nespen, ${ }^{\star}$ W. Van Straalen, $\ddagger$ and V. \\ Fievez $^{\star 2}$ \\ *Laboratory for Animal Nutrition and Animal Product Quality, Faculty of Bioscience Engineering, \\ Ghent University, Proefhoevestraat 10, 9090 Melle, Belgium \\ †Animal Nutrition Group, Wageningen University, Marijkeweg 40, 6709 PG Wageningen, the Netherlands \\ ¥Schothorst Feed Research, Meerkoetenweg 26, 8200 AM Lelystad, the Netherlands
}

\begin{abstract}
Two experiments with rumen-fistulated dairy cows were conducted to evaluate the effects of feeding docosahexaenoic acid (DHA; C22:6 n-3)-enriched diets or diets provoking a decreased rumen $\mathrm{pH}$ on milk fatty acid composition. In the first experiment, dietary treatments were tested during 21-d experimental periods in a $4 \times 4$ Latin square design. Diets included a control diet, a starch-rich diet, a bicarbonate-buffered starchrich diet, and a diet supplemented with DHA-enriched micro algae [Schizochytrium sp., $43.0 \mathrm{~g} / \mathrm{kg}$ of dry matter intake (DMI)]. Algae were supplemented directly through the rumen fistula. The total mixed ration consisted of grass silage, corn silage, soybean meal, and a standard or glucogenic concentrate. The glucogenic and buffered glucogenic diet had no effect on rumen fermentation and milk fatty acid composition because, unexpectedly, no reduced rumen $\mathrm{pH}$ was detected. The algae diet had no effect on rumen $\mathrm{pH}$ but provoked decreased butyrate and increased isovalerate molar proportions in the rumen. In addition, algae supplementation affected rumen biohydrogenation of linoleic and linolenic acid as reflected in the modified milk fatty acid composition toward increased conjugated linoleic acid (CLA) cis-9 trans-11, CLA trans-9 cis-11, C18:1 trans-10, C18:1 trans-11, and C22:6 n-3 concentrations. Concomitantly, on average, a $45 \%$ decrease in DMI and milk yield was observed. Based on these drastic and impractical results, a second animal experiment was performed for $20 \mathrm{~d}$ in which $9.35 \mathrm{~g} / \mathrm{kg}$ of total DMI of algae were incorporated in the concentrate and supplemented to 3 rumen-fistulated cows. Algae concentrate feeding increased rumen $\mathrm{pH}$, which was associated with decreased rumen short-chain fatty acid concentrations.
\end{abstract}

Received March 14, 2008.

Accepted August 17, 2008.

${ }^{1}$ These authors contributed equally to this study.

${ }^{2}$ Corresponding author: Veerle.Fievez@UGent.be
Moreover, a different shift in rumen short-chain fatty acid proportions was observed compared with the first experiment because molar proportions of butyrate, isobutyrate, and isovalerate increased, whereas acetate molar proportion decreased. The milk fatty acid profile changed as in experiment 1 . However, the decrease in DMI and milk yield was less pronounced (on average $10 \%$ ) at this algae supplementation level, whereas milk fat percentage decreased from 47.9 to $22.0 \mathrm{~g} / \mathrm{kg}$ of milk after algae treatment. In conclusion, an algae supplementation level of about $10 \mathrm{~g} / \mathrm{kg}$ of DMI proved effective to reduce the milk fat content and to modify the milk fatty acid composition toward increased CLA cis-9 trans-11, C18:1 trans, and DHA concentrations.

Key words: docosahexaenoic acid, biohydrogenation, trans fatty acid, conjugated linoleic acid

\section{INTRODUCTION}

Rumen biohydrogenation of linoleic (C18:2 n-6) and linolenic (C18:3 n-3) acids might be altered when feeding diets that provoke a low ruminal $\mathrm{pH}$ or that are enriched with polyunsaturated fatty acids (PUFA; Baer et al., 2001; Chilliard et al., 2001; Bauman and Griinari, 2003). A decline in rumen $\mathrm{pH}$ is often observed with high-concentrate/low-forage diets (Kalscheur et al., 1997) or by increasing the content of readily fermentable carbohydrates in the concentrate (Martin et al., 2006). Simultaneously with a low rumen $\mathrm{pH}$, microbial processes are affected, including the biohydrogenation of unsaturated C18 fatty acids (Van Nevel and Demeyer, 1996). Dietary supply of PUFA is achieved through addition of vegetable oils (e.g., sunflower oil, linseed oil) or marine products (e.g., fish oil, algae). In the rumen, these PUFA (C18:2 n-6, C18:3 n-3, C22:6 n-3) also affect microbial processes inducing incomplete C18 biohydrogenation (Chow et al., 2004; Loor et al., 2005b). As a result of this incomplete rumen biohydrogenation, several C18:1 trans fatty acids and conjugated linoleic acid (CLA) isomers accumulate in the rumen, which is reflected in the milk by an altered milk fatty 
acid composition, associated or not with a reduced milk fat content (Chilliard et al., 2007).

In the present in vivo research, 2 dietary treatments were designed aiming at partially inhibiting or shifting rumen C18 biohydrogenation. The first diet was designed to induce a low rumen $\mathrm{pH}$ by feeding a starch-rich concentrate and was expected to be associated with high concentrations of C18:1 trans $(\boldsymbol{t})-10$ (AbuGhazaleh and Jacobson, 2007). The second diet provided docosahexaenoic acid (DHA; C22:6 n-3) in the rumen by supplementation of DHA-enriched micro algae and was expected to result mainly in high concentrations of C18:1 t11 or C18:1 t10 concentrations, in addition to increased C18:2 t11 cis( c)-15 (Shingfield et al., 2003; Boeckaert et al., 2007b). The effect of these dietary treatments on rumen fermentation and milk fatty acid profiles was monitored and compared with a control diet, without micro algae and reduced dietary starch, as well as with a buffered high-starch diet. Concomitant shifts in rumen biohydrogenation and the rumen microbial ecosystem, induced by the algae diet, are reported elsewhere (Boeckaert et al., 2008).

\section{MATERIALS AND METHODS}

\section{Animals and Diets}

Experiment 1. All animal experiments were supervised by a qualified veterinarian and approved by the Institutional Animal Care and Use Committee of the Ghent University, Belgium (acceptance no. EC 2005/45) according to the guidelines imposed by the European Council in 1995. Four primiparous, rumen-cannulated (10 cm i.d., Bar-Diamond Inc., Parma, ID) lactating Holstein cows ( $46 \pm 17$ DIM at the beginning of the experiment) were used in a $4 \times 4$ Latin square design during four 21-d periods. Dietary treatments were 1) a TMR with $33.3 \%$ grass silage, $33.3 \%$ corn silage, and $33.3 \%$ of a standard dairy concentrate $(\mathbf{C O N}) ; 2)$ the $\mathrm{CON}$ diet in which the concentrate was replaced by a glucogenic concentrate rich in $\operatorname{starch}(\mathbf{G L U}) ; 3$ ) the GLU diet supplemented with bicarbonate buffer (GLB); and 4) the CON diet in which the concentrate was partially replaced by DHA-enriched micro algae (Schizochytrium sp., DHA Gold, Martek Biosciences Corp., Columbia, MD; ALG-1). Formulation of the glucogenic concentrate was based on a previous experiment in which feeding (400 g/ $\mathrm{kg}$ of DM) multiparous lactating dairy cows with this type of concentrate resulted in greater proportions of C18:1 t10 in milk and reduced milk fat content (our unpublished data). In the current trial, however, concentrate supplementation levels were lower $(306 \mathrm{~g} / \mathrm{kg}$ of DM) to prevent severe rumen acidosis in primiparous animals. All diets were formulated to meet the cows' nutrient requirements and to balance dietary net energy (VEM; VEM = feed unit milk; 1,000 VEM = 6.9 MJ; Van Es, 1978) to protein (DVE; true protein digested in the small intestine; Tamminga et al., 1994) ratio calculated for a production rate of $25 \mathrm{~kg}$ of milk/d. Therefore, the amount of standard concentrate and soybean meal was adjusted in the ALG diet because of the relatively high fat content of the DHA-enriched algae (Boeckaert et al., 2007a). The animals were fed twice daily, just before milking, at 0730 and $1930 \mathrm{~h}$ and had unlimited access to water. Orts were collected daily before the evening feeding. The ingredient and chemical composition of the different diets are presented in Table 1 , and the formulation and chemical composition of the experimental concentrates is given in Table 2 . The level of algae supplementation was based on the results of in vitro incubations with DHA-enriched algae on rumen fatty acid metabolism (Boeckaert et al., 2007b; Fievez et al., 2007a). The amount of DHA Gold, introduced in 2 equal daily portions via the rumen fistula, was based on the feed intake of the previous day and was increased proportionally during the adaptation period (d 1 to 10 ) to $2 \%$ (on fresh material) throughout the experimental period (d 10 to 21). The gradual increase was as follows (DHA Gold, \% of fresh feed intake of previous day): d $1=0.25 \%$; d $2=0.50 \%$; d $3=0.75 \%$; d 4 and d 5 $=1.00 \% ; \mathrm{d} 6=1.25 \% ; \mathrm{d} 7$ and $\mathrm{d} 8=1.50 \%$; $\mathrm{d} 9=$ $1.75 \%$, and from d 10 onward $=2.00 \%$. During the algal supplementation period, one cow got sick (digestive upset) on d 16. Therefore, algal supplementation was stopped and the data of the algae treatment for this cow were excluded from all statistical analyses. The chemical composition of DHA Gold was described previously in Boeckaert et al. (2007a) with DHA Gold containing $198 \mathrm{~g}$ of DHA $/ \mathrm{kg}$ of DM. Cows were housed in a tie-stall barn and had free access to the TMR. The feed was weighed twice a week, mixed manually, and kept at $4^{\circ} \mathrm{C}$. At each weighing, a representative sample $(100 \mathrm{~g})$ of corn silage and grass silage was taken and stored at $-20^{\circ} \mathrm{C}$. Before chemical and fatty acid analyses, samples were pooled per period. The standard and glucogenic concentrate $(2.5 \mathrm{~g})$ and the micro algae $(1 \mathrm{~g})$ were sampled in duplicate for chemical (only performed for algae) and fatty acid analyses. Cows were milked at 0730 and $1930 \mathrm{~h}$.

Experiment 2. In a second experiment, 3 rumencannulated (10 cm i.d., Bar-Diamond Inc.) HolsteinFriesian cows (612 $\pm 32 \mathrm{~kg}$ of BW) in mid lactation $(172 \pm 45$ DIM) were used to examine milk fatty acid composition responses to algae feeding during $20 \mathrm{~d}$. Differences compared with the algae diet in experiment 1 were 1) the inclusion of the algae in a concentrate, 2) lesser proportions of algae in the diet $(9.35 \mathrm{~g}$ of DHA Gold/kg of DM), and 3) the experimental set-up, which 
Table 1. Total mixed ration ingredients, chemical composition, and fatty acid composition of the control $(\mathrm{CON})$, glucogenic (GLU), buffered glucogenic (GLB), and algae-supplemented (ALG-1) diets (experiment 1)

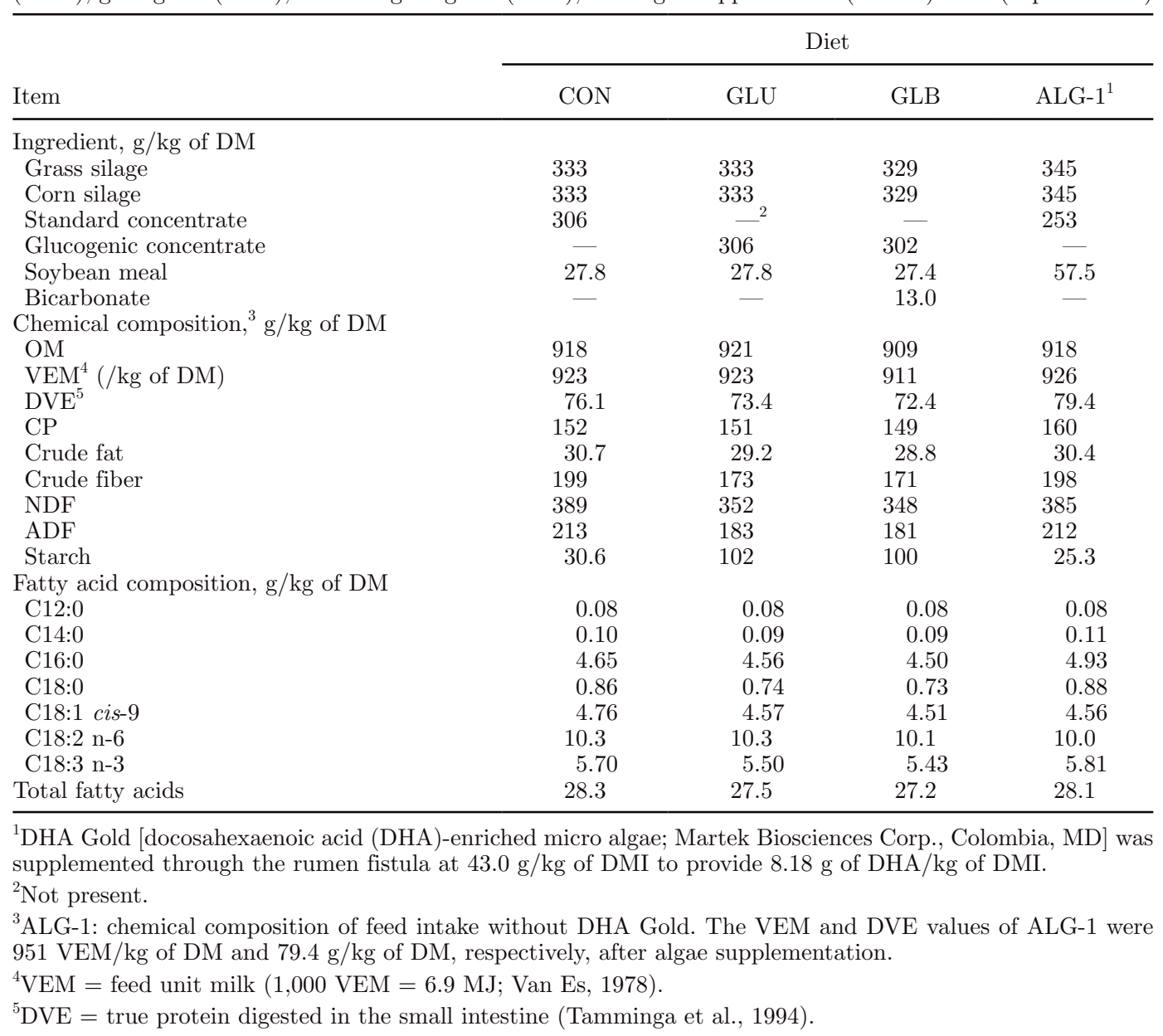

was not designed as a Latin square but concerned a period without algae supplementation with sampling 2 $\mathrm{d}$ before the start of the supplementation and $3 \mathrm{wk}$ of algae supplementation with samplings throughout this period. The algae supplementation level in the experiment was based on results obtained during the adaptation period in experiment 1 , showing $0.5 \%$ of algae inclusion (around $10 \mathrm{~g} / \mathrm{kg}$ of DMI) decreased milk fat without adverse effects on DMI and milk production. The basal diet consisted of a TMR based on grass silage, corn silage, wheat, straw, rapeseed meal, soybean meal, and cane molasses. The concentrate (without algae before supplementation) was offered in 2 equal portions after the morning $(0900 \mathrm{~h})$ and evening (2100 h) milking. During the supplementation period, after 15 min of feeding concentrate, refusals were placed into the rumen via the fistula to ensure each cow had its allotment of DHA-containing concentrate. This was only required on the first day of algae concentrate feeding. After concentrate feeding, the TMR was offered ad libitum (60 kg of fresh matter/d). Grass silage, corn silage, and the concentrate were sampled 4 times during the experimental period and stored frozen. Samples were freeze-dried and pooled per feed component before fatty acid analysis. Ingredient and chemical composition of the diet before $(\mathrm{d}-2)$ and during algae concentrate feeding (ALG-2) is given in Table 3. The concentrate formulations are outlined in Table 4.

\section{Measurement and Sampling}

Experiment 1. Dry matter intake and milk production were recorded daily throughout the experiment. Dry matter intake was determined by subtracting feed orts from the offered feed, with the DM content of the orts obtained by drying a subsample (200 g) during $48 \mathrm{~h}$ at $50^{\circ} \mathrm{C}$. Rumen samples were collected on d 1 , $3,5,8,10,12,15,17$, and 19 at $2,4,6,8,10$, and 12 $\mathrm{h}$ after morning feeding by sampling in different areas of the rumen. After rumen pH measurement (PHM62 standard $\mathrm{pH}$ meter, Radiometer, Copenhagen, Denmark), $20 \mathrm{~mL}$ of rumen fluid was acidified $(2 \%)$ with phosphoric:formic acid (10:1, vol/vol) and centrifuged for $10 \mathrm{~min}$ at 30,000 $\times g(\mathrm{MSE}$, Amsterdam, the Neth- 
Table 2. Ingredient and chemical composition of concentrates (experiment 1)

\begin{tabular}{|c|c|c|}
\hline Item & $\begin{array}{l}\text { Standard } \\
\text { concentrate }\end{array}$ & $\begin{array}{l}\text { Glucogenic } \\
\text { concentrate }\end{array}$ \\
\hline \multicolumn{3}{|l|}{ Ingredient, $\mathrm{g} / \mathrm{kg}$ of product } \\
\hline Rapeseed meal & 80.0 & 106 \\
\hline Corn & -1 & 127 \\
\hline Corn middlings & 300 & 300 \\
\hline Beet pulp & 255 & - \\
\hline Wheat & 9.70 & 266 \\
\hline Wheat middlings & - & 70.0 \\
\hline Peas & 92.0 & 50.4 \\
\hline Soybean hulls & 171 & 17.8 \\
\hline Formaldehyde-treated soybean meal & 27.2 & - \\
\hline Cane molasses & 40.0 & 40.0 \\
\hline Soybean oil & 10.0 & - \\
\hline Chalk & 5.70 & 12.0 \\
\hline Salt & 2.70 & 3.60 \\
\hline Premix & 7.50 & 7.50 \\
\hline \multicolumn{3}{|l|}{ Chemical composition, $\mathrm{g} / \mathrm{kg}$ of DM } \\
\hline $\mathrm{OM}$ & 929 & 937 \\
\hline $\mathrm{VEM}^{2}(/ \mathrm{kg}$ of $\mathrm{DM})$ & 1,062 & 1,076 \\
\hline $\mathrm{DVE}^{3}$ & 94.0 & 85.0 \\
\hline $\mathrm{CP}$ & 156 & 155 \\
\hline Crude fiber & 144 & 60.0 \\
\hline Crude fat & 30.0 & 25.0 \\
\hline NDF & 339 & 217 \\
\hline $\mathrm{ADF}$ & 177 & 78.0 \\
\hline Acid detergent lignin & & - \\
\hline Starch & 100 & 333 \\
\hline Sugars & 73 & 51 \\
\hline
\end{tabular}

${ }^{1}$ Not present.

${ }^{2} \mathrm{VEM}=$ feed unit milk $(1,000 \mathrm{VEM}=6.9 \mathrm{MJ}$; Van Es, 1978).

${ }^{3} \mathrm{DVE}=$ true protein digested in the small intestine (Tamminga et al., 1994).

erlands). The supernatant was used for short-chain fatty acid (SCFA) analysis by GLC (Shimadzu GC14A, Shimadzu, Hertogenbosch, the Netherlands) as described by Van Nevel and Demeyer (1977). Milk was sampled on d $1,3,5,8,10,12,15,17$, and 19 at each milking, after which morning and evening milks were pooled to obtain 2 daily samples. One $30-\mathrm{mL}$ aliquot containing preservative $(8 \mathrm{mg}$ of bronopol and $0.3 \mathrm{mg}$ of natamycine) was stored at $4^{\circ} \mathrm{C}$ until used for prediction of fat, protein, lactose, and urea by mid infrared spectrophotometry (MilkoScan 4000/FT6000, Foss, Amersfoort, the Netherlands). Another $30-\mathrm{mL}$ aliquot was stored at $-20^{\circ} \mathrm{C}$ for lipid extraction and fatty acid analysis.

Experiment 2. Dry matter intake was determined $2 \mathrm{~d}$ before supplementation of the algae concentrate began and on d 6, 13, and 20 after the start of the algae concentrate feeding. Orts were collected and the DM content of orts, obtained by drying a subsample (approximately $200 \mathrm{~g}$ ) during $24 \mathrm{~h}$ at $70^{\circ} \mathrm{C}$, was determined to calculate the DMI of the TMR. Rumen fluid was collected on the same days just before $(0 \mathrm{~h})$ and 1, 2, 4, and $6 \mathrm{~h}$ after the morning feeding. Equal amounts of rumen fluid were collected from the front
Table 3. Ingredient, chemical, and fatty acid composition of the diet before $(\mathrm{d}-2)$ and during algae supplementation (ALG-2) (experiment 2)

\begin{tabular}{lcc}
\hline Item & $\mathrm{d}-2$ & $\mathrm{ALG}-2$ \\
\hline Ingredient, g/kg of DM & & \\
Grass silage & 412 & 401 \\
Corn silage & 281 & 273 \\
Wheat & 83.7 & 81.3 \\
Extracted rapeseed meal & 62.7 & 61.0 \\
Soybean meal & 62.7 & 61.0 \\
Straw & 21.6 & 21.0 \\
Standard concentrate & 75.7 & 16.2 \\
Algae concentrate & - & 85.0 \\
Chemical composition, g/kg of DM & & \\
OM & 930 & 933 \\
CP & 158 & 160 \\
Crude fat & 30.9 & 34.4 \\
Crude fiber & 197 & 189 \\
NDF & 398 & 383 \\
ADF & 223 & 213 \\
Fatty acid composition, g/kg of DM & & \\
C12:0 & 1.15 & 0.82 \\
C14:0 & 0.43 & 0.90 \\
C16:0 & 3.14 & 4.54 \\
C18:0 & 0.45 & 0.45 \\
C18:1 cis-9 & 3.88 & 3.56 \\
C18:2 n-6 & 6.32 & 6.58 \\
C18:3 n-3 & 4.14 & 4.30 \\
C22:6 n-3 & - & 2.09 \\
Total fatty acids & 21.4 & 26.4 \\
\hline
\end{tabular}

${ }^{1}$ Not present.

and middle of the ventral sac and from the cranial sac using a solid, perforated plastic tube $(85 \mathrm{~cm}$ long, 2.5 $\mathrm{cm}$ in diameter). Rumen $\mathrm{pH}$ was measured immediately after sampling ( $\mathrm{pH}$ electrode HI 1230, Hanna Instruments B.V., Ijsselstein, the Netherlands). After rumen $\mathrm{pH}$ measurement, a subsample of rumen fluid was taken, acidified with phosphoric acid, and stored at $-20^{\circ} \mathrm{C}$ pending SCFA analyses by GC (GC-type Fisons HRGC MEGA2, Milan, Italy) as described by Chilibroste et al. (1998). Milk production was recorded daily. Milk was sampled $1 \mathrm{~d}$ before and $2,4,6,9,11$, $13,16,18$, and $20 \mathrm{~d}$ after the algae concentrate feeding started. Aliquots of milk $(10 \mathrm{~mL})$ were collected in duplicate at each milking. One aliquot was stored at $4^{\circ} \mathrm{C}$ using sodium azide and bronopol as preservative and spectrophotometrically analyzed for fat, protein, and lactose contents according to ISO 9622 (ISO, 1999; Melkcontrolestation, Zutphen, the Netherlands). The other aliquot of milk was collected without preservative and stored frozen. Before fatty acid analysis, samples of 2 consecutive milkings (i.e., evening and morning milking) were pooled.

\section{Analysis}

Analysis of the chemical composition of corn silage, grass silage, and micro algae in experiment 1 consisted of 
determination of $\mathrm{CP}$, according to the Kjeldahl method (European Community, 1993); ADF and NDF using the method of Van Soest et al. (1991); and crude fat with the Soxhlet method according to ISO 1443 (ISO, 1973). The chemical composition of the concentrates and soybean meal in experiment 1 was calculated from Centraal Veevoederbureau tables (CVB, 2005) and the ingredient composition of the concentrates. For experiment 2, near infrared spectroscopy (Blgg, Oosterbeek, the Netherlands) was used to determine the chemical composition of corn silage and grass silage, whereas the chemical composition of the remaining compounds was calculated from Centraal Veevoederbureau tables (CVB, 2005) and the ingredient composition of the concentrates.

Fatty acid extraction followed an adapted Folch method (Folch et al., 1957) with chloroform:methanol $(2: 1, \mathrm{vol} / \mathrm{vol})$. Adaptations were as described by Lourenço et al. (2007) for corn silage (5 g) and grass silage (5 g), by Chow et al. (2004) for both concentrates (2.5 $\mathrm{g})$ and soybean meal (2.5 g), and by Raes et al. (2001) for micro algae $(1 \mathrm{~g})$. Nonadecanoic acid (C19:0, Sigma, Bornem, Belgium) was added as the internal standard. Fatty acids in extracts were methylated as described by Raes et al. (2001) with $\mathrm{NaOH}: \mathrm{MeOH}(0.5 \mathrm{~mol} / \mathrm{L})$ followed by $\mathrm{HCl} / \mathrm{MeOH}(1: 1, \mathrm{vol} / \mathrm{vol})$. The fatty acid methyl esters (FAME) were extracted twice with 2 $\mathrm{mL}$ of hexane, and pooled extracts were evaporated to dryness under $\mathrm{N}_{2}$. The residue was dissolved in $1 \mathrm{~mL}$ of hexane and analyzed by GC (HP 6890, HewlettePackard, Brussels, Belgium) on a CP-Sil88 column for FAME $(100 \mathrm{~m} \times 250 \mu \mathrm{m} \times 0.2 \mu \mathrm{m}$, Chrompack, Middelburg, the Netherlands; Raes et al., 2001). Peaks were identified by comparing the retention times with those of the corresponding standards (Sigma; Nu-Chek Prep., Elysian, MN).

Milk fat was extracted according to reference procedures (IDF, 1987) as described previously (Vlaeminck et al., 2005). Briefly, in the first step, samples were extracted with ammonium hydroxide solution, ethanol, diethyl ether, and petroleum ether. In the second extraction step, ethanol, diethyl ether, and petroleum ether were used, and in the final extraction step, the solvents used were diethyl ether and petroleum ether. Extracts from the 3 consecutive steps were combined, evaporated, methylated, and analyzed separately for SCFA (C4:0 to C10:0) and medium- and long-chain fatty acids (C12:0 to C24:0). Standard curves were used to determine the response factors for milk SCFA, using tridecanoic acid (C13:0, Sigma) as the internal standard, whereas the other fatty acids were quantified with nonadecanoic acid (C19:0, Sigma) as the internal standard. Methylation and analysis by GLC were described previously by Vlaeminck et al. (2005). Fatty acid methyl esters
Table 4. Ingredient composition of concentrates (experiment 2)

\begin{tabular}{|c|c|c|}
\hline Item & $\begin{array}{l}\text { Standard } \\
\text { concentrate }\end{array}$ & $\begin{array}{c}\text { Algae } \\
\text { concentrate }\end{array}$ \\
\hline \multicolumn{3}{|l|}{ Ingredient, $\mathrm{g} / \mathrm{kg}$ of product } \\
\hline Beet pulp & 250 & 150 \\
\hline Palm kernel, expeller & 200 & -1 \\
\hline Rapeseed meal, extracted & 130 & - \\
\hline Soybean hulls & 100 & 100 \\
\hline Potato juice, concentrated & 100 & - \\
\hline Rapeseed expeller & 52.0 & - \\
\hline Corn middlings & 43.0 & - \\
\hline Cane vinasses & 40.0 & - \\
\hline Wheat middlings & 26.0 & 100 \\
\hline Citrus pulp, dehydrated & 25.0 & 50.0 \\
\hline Cane molasses & 20.0 & 60.0 \\
\hline Minerals/vitamins & 10.0 & - \\
\hline Soybean meal & - & 30.0 \\
\hline Wheat & - & 200 \\
\hline Linseed meal & - & 100 \\
\hline Corn gluten meal & - & 100 \\
\hline DHA Gold $^{2}$ & - & 110 \\
\hline \multicolumn{3}{|l|}{$\begin{array}{l}\text { Chemical composition, } \\
\mathrm{g} / \mathrm{kg} \text { of DM }\end{array}$} \\
\hline $\mathrm{OM}$ & 902 & 954 \\
\hline $\operatorname{VEM}^{3}(/ \mathrm{kg}$ of $\mathrm{DM})$ & 1,107 & 1,148 \\
\hline $\mathrm{DVE}^{4}$ & 106 & 139 \\
\hline $\mathrm{CP}$ & 193 & 198 \\
\hline Crude fiber & 184 & 99.0 \\
\hline Crude fat & 46.0 & 82.0 \\
\hline $\mathrm{NDF}$ & 409 & 232 \\
\hline $\mathrm{ADF}$ & 251 & 125 \\
\hline Acid detergent lignin & 44.0 & 14.0 \\
\hline Starch & 45.0 & 173 \\
\hline
\end{tabular}

${ }^{1}$ Not present.

${ }^{2}$ Schizochytrium sp., DHA Gold, Martek Biosciences Corp., Colombia, MD.

${ }^{3} \mathrm{VEM}=$ feed unit milk (1,000 VEM = 6.9 MJ; Van Es, 1978).

${ }^{4} \mathrm{DVE}=$ true protein digested in the small intestine (Tamminga et al., 1994).

were identified from external standards (S37, Supelco, Poole, UK; ME61, C18:2 c9t11, C18:2 t10c12, odd- and branched-chain fatty acids, Larodan Fine Chemicals $\mathrm{AB}$, Malmö, Sweden) and quantified using the internal standard. Fatty acids C18:1 t12, C18:1 c12, C18:1 c13, C18:1 c14+t16, C18:1 c15, and CLA t9c11 were identified according to the elution sequence reported by Ratnayake (1998) and Shingfield et al. (2006). In experiment 1, C18:1 t12 could not be separated from C18:1 c9. Erroneous analytical results for C17 fatty acids cannot be excluded because of co-elution of the peaks with $\mathrm{C} 16: 1$ cis or trans fatty acids, as observed for anteiso C17:0 and C16:1 c9, for example (Precht and Molkentin, 2000).

\section{Statistical Analysis}

Experiment 1. Before statistical analysis, the mean of the 3 sampling days during the experimental period (d 15, 17, and 19) was calculated. Data were analyzed 
Table 5. Rumen pH, molar proportions of short-chain fatty acids (SCFA) and total SCFA concentrations of cows fed the control (CON), glucogenic (GLU), buffered glucogenic (GLB), and algae supplemented (ALG-1) diets $(\mathrm{n}=90)(\text { experiment } 1)^{1}$

\begin{tabular}{|c|c|c|c|c|c|c|c|c|}
\hline \multirow[b]{2}{*}{ Item } & \multicolumn{4}{|c|}{ Diet } & \multirow[b]{2}{*}{ SEM } & \multicolumn{3}{|c|}{$P$-value ${ }^{2}$} \\
\hline & $\mathrm{CON}$ & GLU & GLB & ALG-1 & & $D$ & $T$ & $D \times T$ \\
\hline Acetate & 621 & 615 & 614 & 593 & 13.5 & 0.453 & $<0.001$ & 0.364 \\
\hline Propionate & 197 & 205 & 200 & 231 & 12.6 & 0.272 & $<0.001$ & 0.075 \\
\hline Isobutyrate & 7.65 & 7.94 & 8.00 & 7.96 & 0.536 & 0.907 & 0.001 & 0.765 \\
\hline Isovalerate & $10.8^{\mathrm{b}}$ & $13.2^{\mathrm{b}}$ & $14.3^{\mathrm{b}}$ & $31.4^{\mathrm{a}}$ & 3.76 & $<0.001$ & 0.118 & 0.575 \\
\hline Total SCFA, mmol/L & 99.4 & 99.1 & 101 & 101 & 7.16 & 0.956 & $<0.001$ & 0.497 \\
\hline
\end{tabular}

${ }^{\mathrm{a}, \mathrm{b}}$ Means within a row with different superscripts differ $(P<0.05)$.

${ }^{1}$ Data shown are the mean of values on $\mathrm{d} 15,17$ and 19 .

${ }^{2} D=$ effect of diet; $T=$ effect of time of sampling after morning feeding $(2,4,6,8,10$, and $12 \mathrm{~h}) ; D \times T=$ interaction between diet and time of rumen sampling.

using the MIXED procedure of SAS (version 9.1; SAS Institute, 2004). Rumen variables were analyzed with the fixed effects of period, diet, time of sampling, and the interaction of diet with time and cow as a random effect, assuming an autoregressive order-one covariance structure fitted on the basis of Akaike information and Schwarz Bayesian model fit criteria. Time of sampling was treated as a repeated measure. The statistical model for DMI, milk production, and milk fatty acids included the fixed effects of period and diet and the random effect of cow. Least squares means are reported and significance was declared at $P<0.05$. Differences among diets were evaluated using a multiple comparison test following the Tukey-Kramer method.

Experiment 2. Data were statistically analyzed using the MIXED procedure of SAS Institute (version 9.1, SAS Institute, 2004). The statistical model for rumen variables included the fixed effect of day and time of sampling and their interaction and the random effect of cow assuming an autoregressive order-one covariance structure fitted on the basis of Akaike information and Schwarz Bayesian model fit criteria. Time of sampling was treated as a repeated measure. The statistical model for DMI, milk production, and milk fatty acids included the fixed effects of day and the random effect of cow assuming an autoregressive order-one covariance structure fitted on the basis of Akaike information and Schwarz Bayesian model fit criteria. Day was treated as a repeated measure. Least squares means are reported and significance was declared at $P<0.05$. Differences among days on algae feeding were evaluated using a multiple comparison test following the Tukey-Kramer method.

\section{RESULTS}

\section{Rumen Fermentation}

Experiment 1. Feeding the different diets had no effect on rumen $\mathrm{pH}$ or total SCFA concentrations

Table 6. Effect of time of algae concentrate feeding on rumen $\mathrm{pH}$, molar proportions of short-chain fatty acid (SCFA), and total SCFA concentrations $(\mathrm{n}=60)$ (experiment 2$)$

\begin{tabular}{|c|c|c|c|c|c|c|c|c|}
\hline \multirow[b]{2}{*}{ Item } & \multicolumn{4}{|c|}{ Time } & \multirow[b]{2}{*}{ SEM } & \multicolumn{3}{|c|}{$P$-value ${ }^{1}$} \\
\hline & $\mathrm{d}-2$ & d 6 & d 13 & d 20 & & $D$ & $T$ & $D \times T$ \\
\hline Acetate & $626^{\mathrm{a}}$ & $607^{\mathrm{b}}$ & $605^{\mathrm{b}}$ & $605^{\mathrm{b}}$ & 9.3 & 0.003 & $<0.001$ & 0.025 \\
\hline Propionate & 216 & 216 & 220 & 209 & 7.9 & 0.136 & $<0.001$ & 0.156 \\
\hline Butyrate & $123^{\mathrm{b}}$ & $133^{\mathrm{b}}$ & $131^{\mathrm{b}}$ & $145^{\mathrm{a}}$ & 4.5 & $<0.001$ & $<0.001$ & 0.004 \\
\hline Isovalerate & $12.6^{\mathrm{b}}$ & $19.7^{\mathrm{a}}$ & $19.3^{\mathrm{a}}$ & $18.8^{\mathrm{a}}$ & 2.92 & $<0.001$ & $<0.001$ & 0.643 \\
\hline Total SCFA, mmol/L & $151^{\mathrm{a}}$ & $134^{\mathrm{bc}}$ & $138^{\mathrm{b}}$ & $124^{\mathrm{c}}$ & 3.2 & $<0.001$ & $<0.001$ & 0.249 \\
\hline
\end{tabular}

${ }^{\mathrm{a}-\mathrm{c}}$ Means within a row with different superscripts differ $(P<0.05)$.

${ }^{1} D=$ effect of days on algae concentrate feeding; $T=$ effect of time of sampling just before $(0 \mathrm{~h})$ and $1,2,4$ and $6 \mathrm{~h}$ after the morning feeding; $D \times T=$ interaction between days on algae concentrate feeding and time of rumen sampling. 
Table 7. Effects of the control (CON), glucogenic (GLU), buffered glucogenic (GLB), and algae (ALG-1) diets on DMI, milk yield, and milk composition $(\mathrm{n}=15)(\text { experiment } 1)^{1}$

\begin{tabular}{lcccccc}
\hline & \multicolumn{7}{c}{ Diet } & & \\
\cline { 2 - 5 } Item & CON & GLU & GLB & ALG-1 & SEM & $P$-value ${ }^{2}$ \\
\hline DMI, kg/d & $16.7^{\mathrm{a}}$ & $15.6^{\mathrm{a}}$ & $15.2^{\mathrm{a}}$ & $8.94^{\mathrm{b}}$ & 0.839 & 0.004 \\
Yield, kg/d & & & & & \\
Milk & $23.5^{\mathrm{a}}$ & $21.7^{\mathrm{a}}$ & $22.0^{\mathrm{a}}$ & $13.0^{\mathrm{b}}$ & 1.806 & 0.015 \\
Fat & $0.94^{\mathrm{a}}$ & $0.82^{\mathrm{a}}$ & $0.79^{\mathrm{a}}$ & $0.42^{\mathrm{b}}$ & 0.061 & 0.009 \\
Protein & $0.70^{\mathrm{a}}$ & $0.65^{\mathrm{a}}$ & $0.65^{\mathrm{a}}$ & $0.42^{\mathrm{b}}$ & 0.040 & 0.003 \\
Lactose & $1.11^{\mathrm{a}}$ & $1.03^{\mathrm{a}}$ & $1.05^{\mathrm{a}}$ & $0.54^{\mathrm{b}}$ & 0.095 & 0.015 \\
Concentration, g/kg & & & & & & \\
Fat & 40.2 & 38.0 & 36.1 & 32.2 & 2.52 & 0.199 \\
Protein & 29.7 & 29.9 & 29.7 & 34.1 & 1.85 & 0.366 \\
Lactose & 47.4 & 47.5 & 47.7 & 40.5 & 1.65 & 0.069 \\
\hline
\end{tabular}

a,b Means within a row with different superscripts differ $(P<0.05)$.

${ }^{1}$ Data shown are the means of values on $\mathrm{d} 15,17$, and 19 .

${ }^{2}$ Effect of diet.

(Table 5). Diet ALG-1 changed SCFA molar proportions with decreased butyrate and increased isovalerate proportions compared with CON. Molar proportions of SCFA were not affected by feeding GLU and GLB. Rumen $\mathrm{pH}$, total SCFA concentrations, and SCFA molar proportions, except for isovalerate, changed as time of rumen sampling after morning feeding progressed following diurnal variations.

Experiment 2. Algae concentrate feeding increased rumen $\mathrm{pH}$ and decreased total SCFA concentrations by up to $18 \%$ after $19 \mathrm{~d}$ of treatment (Table 6). Clear shifts occurred within the SCFA molar proportions upon algae supplementation. Acetate and valerate proportions decreased, whereas butyrate, isobutyrate, and isovalerate proportions increased. These shifts were already significant $6 \mathrm{~d}$ after the first introduction of algae, except for butyrate and valerate molar proportions. As in experiment 1 , rumen $\mathrm{pH}$, total SCFA concentrations, and SCFA molar proportions changed with time of rumen sampling after morning feeding following diurnal variations.

\section{Nutrient Intake and Animal Performance}

Experiment 1. The ALG-1 diet strongly decreased DMI and milk, fat, protein, and lactose yields (Table 7); GLU and GLB had no effect on these parameters. None of the diets significantly affected the milk concentrations of fat, protein, and lactose. However, milk lactose concentration tended $(P<0.10)$ to decrease with algae supplementation.

Experiment 2. The decrease in DMI by algae supplementation from d 13 onward was associated with decreased milk, fat, protein, and lactose yields (Table 8 ). The decrease in protein yield mainly followed the decrease in milk yield, whereas the decrease in fat yield was more pronounced. Milk fat concentration was $47.9 \mathrm{~g} / \mathrm{kg}$ of milk before the algae treatment, declined significantly in the beginning of the algae concentrate feeding (d 1 to 8 ), and stabilized at, on average, 22.5 $\mathrm{g} / \mathrm{kg}$ of milk during the last phase of the experimental period (d 12 to 19). Milk protein concentrations were not affected by algae feeding.

\section{Milk Fatty Acid Composition}

Experiment 1. Feeding GLU or GLB did not induce any significant difference in the milk fatty acid composition compared with CON (Table 9). In contrast, ALG-1 altered the milk fatty acid composition remarkably. The proportion of saturated fatty acids (SFA) decreased, whereas PUFA proportions increased. The greater PUFA amount was mainly due to increased proportions of C18:2 t11c15, CLA c9t11, CLA t9c11, and C22:6 n-3 fatty acids. The total monounsaturated (MUFA) and odd- and branched-chain (OBCFA) fatty acid proportions showed no differences between the diets. Of the OBCFA, ALG-1 resulted in increased proportions of iso $\mathrm{C} 13: 0$, anteiso $\mathrm{C} 13: 0$, and anteiso $\mathrm{C} 17: 0$ and a decreased proportion of iso C16:0. In addition, ALG-1 resulted in lesser amounts of C18:2 n-6, whereas most of the rumen biohydrogenation intermediates of C18:3 n-3 and C18:2 n-6 increased. Remarkably, CLA t9c11 was hardly or not detected in milk from non-algae-fed animals, whereas it represented on average $0.2 \mathrm{~g} / 100 \mathrm{~g}$ of milk fatty acids of algae-fed animals. Proportions of CLA t10c12 remained below $0.01 \mathrm{~g} / 100 \mathrm{~g}$ of fatty acids for all dietary treatments and were found to be the lowest in milk from algaefed cows. The proportion of C18:2 t11c15 was 8-fold greater in milk fat from ALG-1 compared with CON. Regarding the C18:1 isomers, different responses to the 
Table 8. Effect of time of algae concentrate feeding on DMI $(\mathrm{n}=12)$, milk yield, and milk composition $(\mathrm{n}=$ 30) (experiment 2)

\begin{tabular}{lcccccc}
\hline & \multicolumn{9}{c}{ Time } & & \\
\cline { 2 - 5 } Item & $\mathrm{d}-2$ & $\mathrm{~d} 6$ & $\mathrm{~d} 13$ & $\mathrm{~d} 20$ & SEM & $P$-value \\
\hline DMI, $\mathrm{kg} / \mathrm{d}$ & $22.5^{\mathrm{a}}$ & $23.4^{\mathrm{a}}$ & $20.8^{\mathrm{b}}$ & $20.9^{\mathrm{b}}$ & 0.57 & 0.003 \\
Yield, kg/d & & & & & & \\
Milk & $26.4^{\mathrm{ab}}$ & $28.1^{\mathrm{a}}$ & $25.3^{\mathrm{bc}}$ & $23.7^{\mathrm{c}}$ & 1.07 & $<0.001$ \\
Fat & $1.27^{\mathrm{a}}$ & $0.95^{\mathrm{b}}$ & $0.58^{\mathrm{c}}$ & $0.52^{\mathrm{c}}$ & 0.092 & $<0.001$ \\
Protein & $0.90^{\mathrm{a}}$ & $0.94^{\mathrm{a}}$ & $0.86^{\mathrm{ab}}$ & $0.78^{\mathrm{b}}$ & 0.056 & 0.016 \\
Lactose & $1.17^{\mathrm{ab}}$ & $1.25^{\mathrm{a}}$ & $1.12^{\mathrm{bc}}$ & $1.03^{\mathrm{c}}$ & 0.048 & $<0.001$ \\
Concentration, g/kg & & & & & & $<0.001$ \\
Fat & $47.9^{\mathrm{a}}$ & $33.8^{\mathrm{b}}$ & $22.5^{\mathrm{c}}$ & $22.0^{\mathrm{c}}$ & 2.61 & 0.650 \\
Protein & 34.0 & 33.5 & 33.8 & 32.9 & 1.26 & 0.147 \\
Lactose & 44.1 & 44.5 & 44.2 & 43.3 & 0.38 & \\
\hline
\end{tabular}

${ }^{\mathrm{a}-\mathrm{c}}$ Means within a row with different superscripts differ $(P<0.05)$.

${ }^{1}$ Effect of days on algae concentrate feeding. Probability for milk yield and milk composition was calculated based on all data (d -1, 2, 4, 6, 9, 11, 13, 16, 18, and 20) incorporated in the statistical model.

algae addition were observed. Most noteworthy was the strong increase of $\mathrm{C} 18: 1 \mathrm{t} 10$ and (to a lesser extent) C18:1 t11 at the expense of C18:1 c12, C18:1 c14+t16, C18:1 c15, and C18:1 t6-t8. The high concentrations of C18 biohydrogenation intermediates in the milk fat of algae-fed cows were accompanied by a strong decrease in $\mathrm{C} 18: 0$ concentration.

Experiment 2. The proportion of SFA decreased, whereas those of MUFA and PUFA increased after algae treatment (Table 10). Lesser SFA amounts were due, in part, to decreased de novo fatty acid synthesis in the mammary gland as shown by the lesser C6:0, C8:0, C10:0, and C12:0 proportions in milk fat from algae-fed cows, in addition to a dramatic decrease in C18:0. The greater MUFA proportions were mainly provoked by the strong increase in C18:1 trans fatty acids, whereas greater PUFA proportions were again associated with increased C18:2 t11c15, CLA c9t11, CLA t9c11, and C22:6 n-3 fatty acid proportions. Proportions of CLA c9t11 and C18:2 t11c15 increased rapidly after $3 \mathrm{~d}$ of algae supplementation, whereas those of CLA t9c11 and C22:6 n-3 showed a more gradual increase as algae concentrate feeding evolved until about $10 \mathrm{~d}$ of algae supplementation (Figure 1). From d 8 after algae supplementation, variations in the milk fat proportions of these hydrogenation intermediates were smaller and coincided with variations in milk fat DHA. Remarkably, CLA t10c12 remained constant during algae concentrate feeding. As observed in experiment 1, algae supplementation strongly increased C18:1 t10 and $\mathrm{C} 18: 1$ t11 proportions at the expense of $\mathrm{C} 18: 1$ c9 proportions (Figure 2). Proportions of both fatty acids increased immediately resulting in average 1.6-, 7.9-, and 10.2-fold increases on d 2, 4, and 6, respectively. After d 6, concentrations of C18:1 t11 decreased slightly and stabilized at $4.5 \mathrm{~g} / 100 \mathrm{~g}$ of fatty acids. In contrast, concentrations of C18:1 t10 further increased reaching a maximum value of $6.3 \mathrm{~g} / 100 \mathrm{~g}$ of fatty acids on d 16. Moreover, increasing proportions of C18:1 c11, C18:1 c13, C18:1 c14+t16, C18:1 c15, C18:1 t6-t8, C18:1 t9, and C18:1 t12 were observed. Also, OBCFA proportions increased with algae concentrate feeding, which was mainly provoked by the 3 -fold increase in the proportion of iso C17:0. However, contents of $\mathrm{C} 17$ fatty acids determined by GC can be too high because of overlaps with C16:1 trans fatty acids (Precht and Molkentin, 2000). Proportions of C15:0 and C17:0 decreased with ALG-2, as did the proportion of iso C15:0. The proportions of iso $\mathrm{C} 16: 0$, anteiso $\mathrm{C} 17: 0$, and $\mathrm{C} 17: 1$ c9 increased.

\section{DISCUSSION}

\section{Rumen Fermentation}

In contrast to the aim of the experimental set-up, increasing the starch content of the concentrate in GLU resulted in only minor changes in DMI, rumen fermentation parameters, and milk production characteristics. Algae supplementation had no effect on rumen $\mathrm{pH}$ when no effect on total SCFA concentrations was observed (experiment 1), whereas rumen $\mathrm{pH}$ increased when total SCFA concentrations decreased (experiment 2). Algae addition also induced shifts in the SCFA proportions. Lesser butyrate and greater isovalerate proportions were observed when $43.0 \mathrm{~g}$ of algae $/ \mathrm{kg}$ of DMI was supplemented directly through the rumen fistula (experiment 1). The decrease in butyrate was associated both with lower protozoal concentrations upon algae feeding and a shift in protozoal and bacterial populations in experiment 1 (Boeckaert et al., 2007a), whereas increased isovalerate proportions can be linked with 
Table 9. Milk fatty acid composition (g/100 g fatty acids) of cows fed a control (CON), glucogenic (GLU), buffered glucogenic (GLB), and algae $\left(\right.$ ALG-1) diets $(\mathrm{n}=15)(\text { experiment } 1)^{1}$

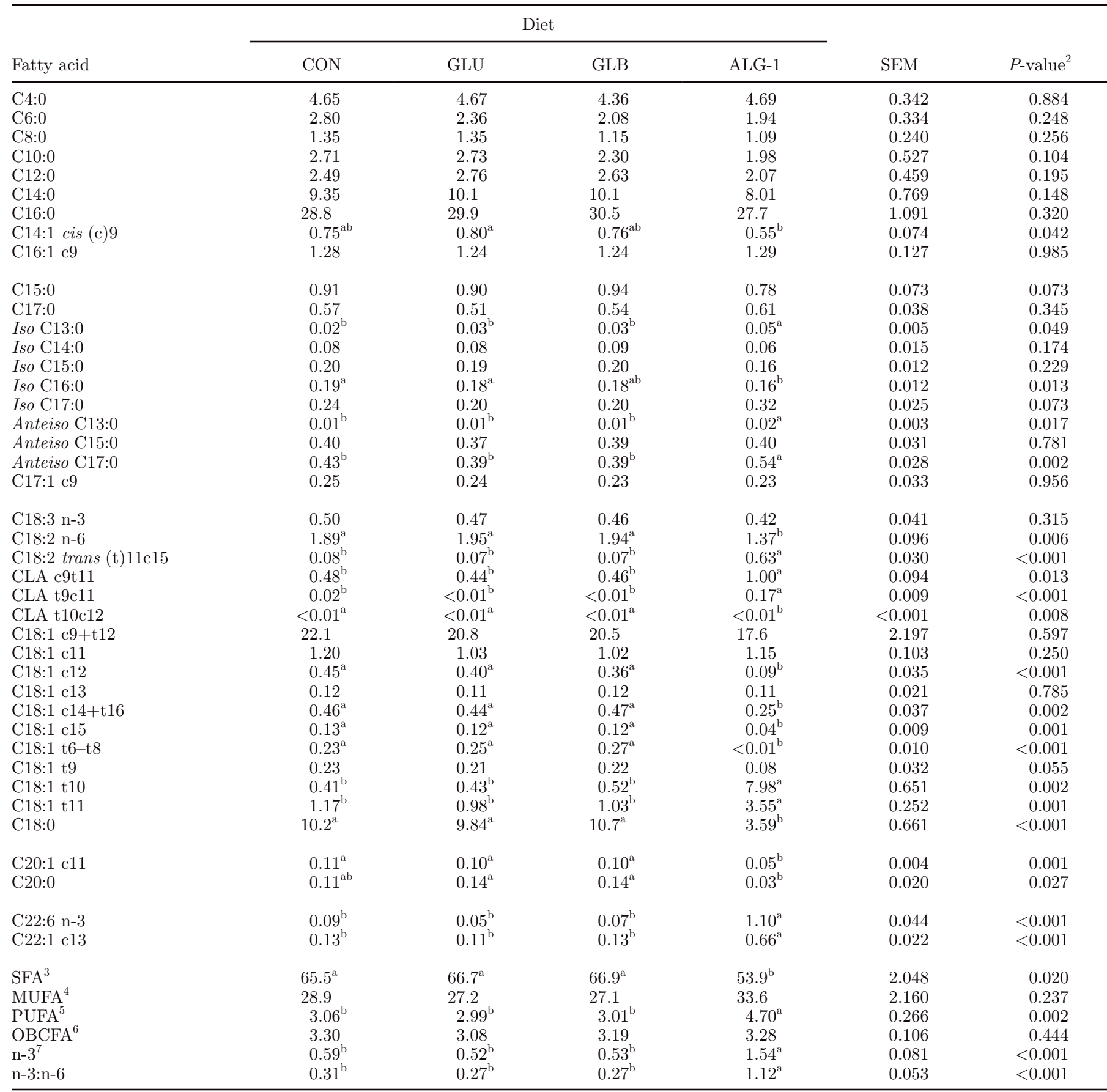

${ }^{\mathrm{a}, \mathrm{b}}$ Means within a row with different superscripts differ $(P<0.05)$.

${ }^{1}$ Data shown are the mean fatty acids present in milk collected on d 15, 17, and 19.

${ }^{2}$ Effect of diet.

${ }^{3}$ Saturated fatty acids $=\Sigma(\mathrm{C} 4: 0, \mathrm{C} 6: 0, \mathrm{C} 8: 0, \mathrm{C} 10: 0, \mathrm{C} 12: 0, \mathrm{C} 13: 0, \mathrm{C} 14: 0, \mathrm{C} 15: 0, \mathrm{C} 16: 0, \mathrm{C} 17: 0, \mathrm{C} 18: 0, \mathrm{C} 20: 0$, iso C13:0, iso C14:0, iso C15:0, iso $\mathrm{C} 16: 0$, iso $\mathrm{C} 17: 0$, anteiso $\mathrm{C} 13: 0$, anteiso $\mathrm{C} 15: 0$, anteiso $\mathrm{C} 17: 0)$.

${ }^{4}$ Monounsaturated fatty acids $=\Sigma(\mathrm{C} 14: 1 \mathrm{c} 9, \mathrm{C} 16: 1 \mathrm{c} 9, \mathrm{C} 17: 1 \mathrm{c} 9, \mathrm{C} 18: 1 \mathrm{c} 9+\mathrm{t} 12, \mathrm{C} 18: 1 \mathrm{c} 11, \mathrm{C} 18: 1 \mathrm{c} 12, \mathrm{C} 18: 1 \mathrm{c} 13, \mathrm{C} 18: 1 \mathrm{c} 14+\mathrm{t} 16, \mathrm{C} 18: 1 \mathrm{c} 15$, C18:1 t6-t8, C18:1 t9, C18:1 t10, C18:1 t11, C20:1 c11, C22:1 c13).

${ }^{5}$ Polyunsaturated fatty acids $=\Sigma(\mathrm{C} 18: 3 \mathrm{n}-3, \mathrm{C} 18: 2 \mathrm{n}-6, \mathrm{C} 18: 2 \mathrm{t} 11 \mathrm{c} 15$, CLA c9t11, CLA t9c11, CLA t10c12, C22:6 n-3).

${ }^{6} \mathrm{Odd}-$ and branched-chain fatty acids $=\Sigma(\mathrm{C} 15: 0, \mathrm{C} 17: 0$, iso C13:0, iso C14:0, iso C15:0, iso C16:0, iso C17:0, anteiso C13:0, anteiso C15:0, anteiso $\mathrm{C} 17: 0, \mathrm{C} 17: 1 \mathrm{c} 9)$.

${ }^{7} \mathrm{n}-3=\Sigma(\mathrm{C} 18: 3$ n-3, C22:6 n-3). 
greater levels of $\mathrm{CP}$ caused by the greater content of soybean meal in the algae diet. However, incorporation of $9.35 \mathrm{~g}$ of algae $/ \mathrm{kg}$ of DMI in the concentrate (experiment 2) increased butyrate as well as isobutyrate and isovalerate proportions, whereas acetate and valerate proportions decreased (experiment 2). Apparently, the effects of dietary marine products on rumen butyrate proportions are highly variable and inconsistent: a decrease in experiment 1, an increase in experiment 2 and Shingfield et al. (2003), and no effect observed by Keady

Table 10. Effect of time of algae concentrate feeding on the milk fatty acid composition (g/100 g of fatty acids) (n = 30) (experiment 2$)$

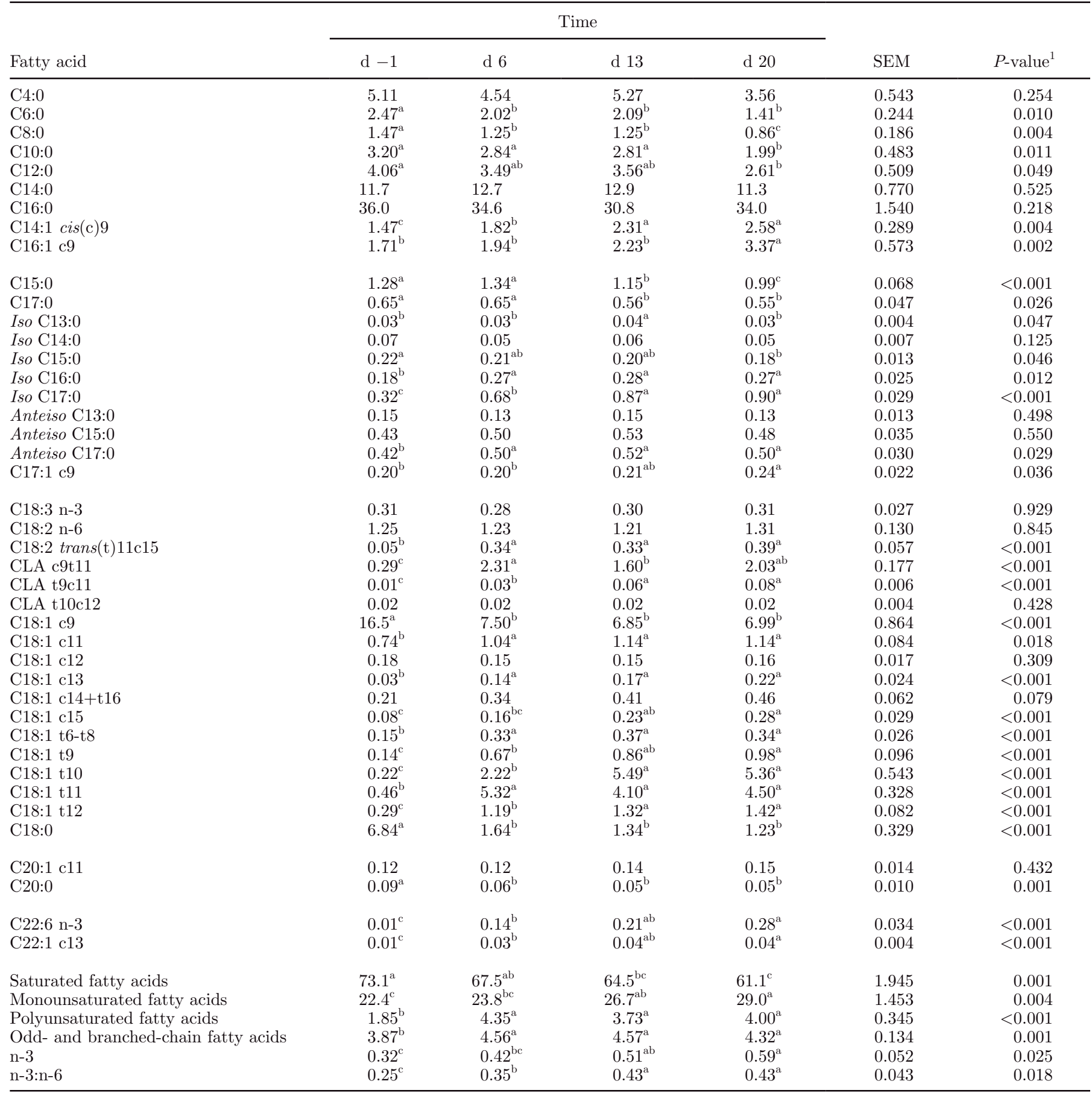

${ }^{\mathrm{a}-\mathrm{c}}$ Means within a row with different superscripts differ $(P<0.05)$.

${ }^{1}$ Effect of days on algae concentrate feeding. Probability was calculated based on all data $(\mathrm{d}-1,2,4,6,9,11,13,16,18$, and 20$)$ incorporated in the statistical model. 
and Mayne (1999). This might relate to differences in supplementation levels. Indeed, Palmquist and Griinari (2006) observed decreased acetate and increased butyrate concentrations at lower fish oil supplementation levels $(10 \mathrm{~g} / \mathrm{kg}$ of DM), whereas the opposite for butyrate was observed at greater supplementation levels $(30 \mathrm{~g} / \mathrm{kg}$ of DM $)$. It is unclear whether a change in the bacterial community or other mechanisms (e.g., change in substrate fermentation by changes in rumen $\mathrm{pH}$ ), or both, were responsible for the increased butyrate concentrations.

\section{Animal Performance}

The algae diet reduced DMI and milk yield by $45 \%$ when $43.0 \mathrm{~g} / \mathrm{kg}$ of DM of algae was supplemented directly through the rumen fistula (experiment 1). Despite the similar amount of algae supplemented (39.7 $\mathrm{g}$ of algae $/ \mathrm{kg}$ of $\mathrm{DM}$ ) in the experiment reported by Franklin et al. (1999), they observed a 20\% decrease in DMI without an effect on milk yield using the same algae species (Schizochytrium). This might relate to the difference in DHA content of the algae in experiment 1 (198 $\mathrm{g}$ of DHA $/ \mathrm{kg}$ of algae) compared with the experiment of Franklin et al. (1999) (53.3 g of DHA $/ \mathrm{kg}$ of algae) resulting in a 2-fold greater DHA intake in the current experiment $(76.1 \mathrm{~g}$ of $\mathrm{DHA} / \mathrm{d}$ in experiment 1 vs. 37.6 g DHA/d in Franklin et al., 1999). Disturbance of the rumen fermentation through PUFA supplementation probably explains most of the reduced DMI (Jenkins, 1993). Incorporating $9.35 \mathrm{~g}$ of algae $/ \mathrm{kg}$ of diet DM in experiment 2 modified milk fat content and milk fatty acid composition without dramatic effects $(10 \%$ reduction) on DMI and milk yield in line with results reported by Franklin et al. (1999). Indeed, despite the lesser amount of algae supplemented in experiment 2 $(9.35 \mathrm{~g}$ of algae $/ \mathrm{kg}$ of DM vs. $39.7 \mathrm{~g}$ of algae $/ \mathrm{kg}$ of DM), DHA intake was similar in both experiments (43.7 vs. $37.6 \mathrm{~g}$ of $\mathrm{DHA} / \mathrm{d}$ in the current experiment 2 and that of Franklin et al., 1999, respectively). The reduced milk fat yield in experiment 2 is consistent with other studies that included marine products such as fish oil, fish meal, or marine algae (Franklin et al., 1999; Donovan et al., 2000; AbuGhazaleh et al., 2004). A decrease in milk fat content was found to be associated with the increase of some particular milk fatty acids. Until now, the biohydrogenation intermediate CLA t10c12 is the only intermediate unequivocally shown to inhibit mammary lipid metabolism (Shingfield and Griinari, 2007), whereas tentative evidence shows that CLA c10t12 and CLA t9c11 also exert antilipogenic effects (Shingfield and Griinari, 2007). Neither CLA t10c12 or CLA c10t12 could explain the diet-induced milk fat depression in the current experiments because CLA t10c12 did not

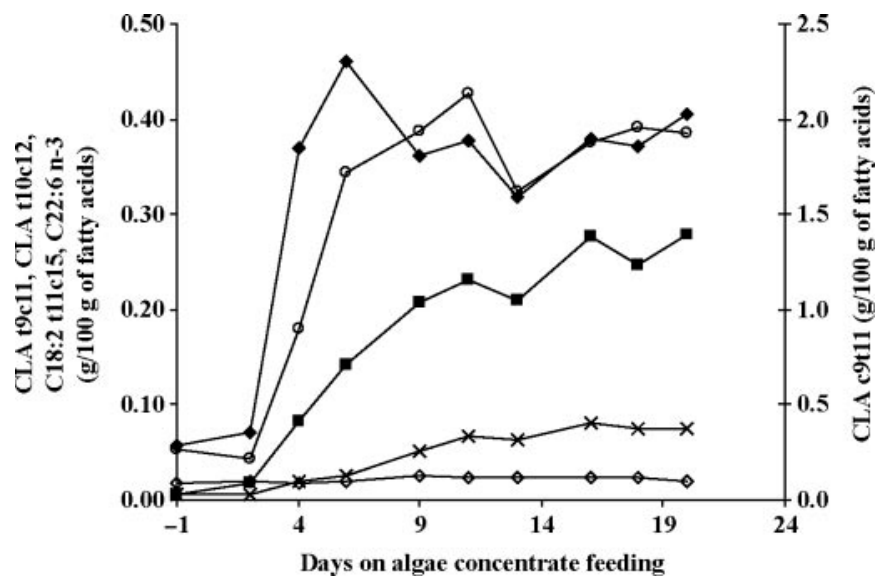

Figure 1. Temporal changes in milk conjugated linoleic acid (CLA) cis-9 trans-11 $\diamond)$, CLA trans-9 cis-11 $(\times)$. CLA trans-10 cis-12 $(\diamond)$, C18:2 trans-11 cis-15 (O), and C22:6 n-3 (ם) concentrations $(\mathrm{g} / 100 \mathrm{~g}$ of fatty acids) in cows fed algae concentrate (experiment 2). Values represent the means of 3 animals, with average SEM of 0.177 ( $)$, $0.006(\times), 0.004(\diamond), 0.057(\bigcirc)$, and $0.034(\mathbf{\square})$.

increase with the algae diet and CLA c10t12 was not detectable in milk. In both experiments, milk CLA t9c11 concentrations increased with the algae diet and the increase was greater in experiment 1 . However, milk fat content was affected only in experiment 2 , suggesting a minor role of this intermediate in milk fat depression in the current experiments. The fatty acid C18:1 t10 has often been associated with milk fat depression although this fatty acid is thought to play no regulatory role in milk fatty acid synthesis (Lock et al., 2007). It has been proposed that the reduced supply of C18:0 for mammary C18:1 c9 synthesis could limit milk fat secretion

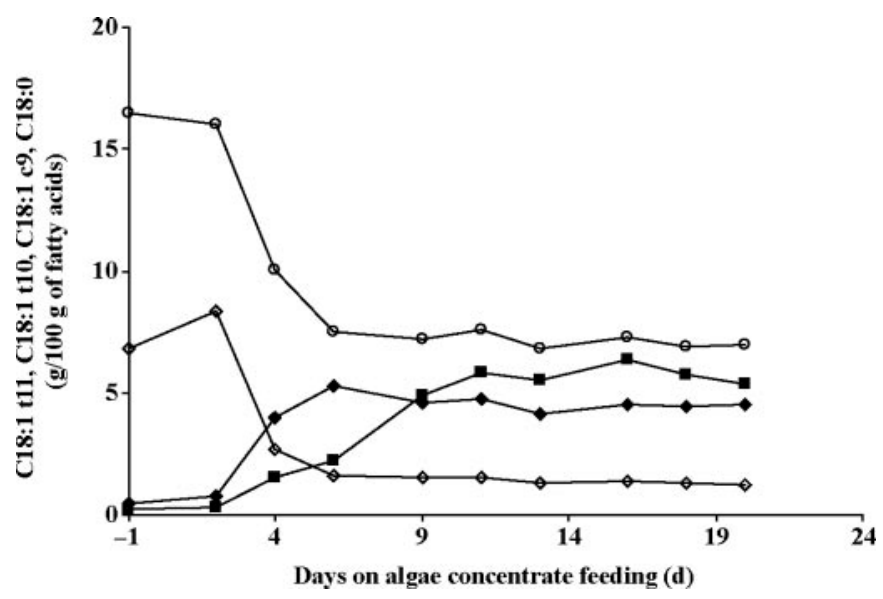

Figure 2. Temporal changes in C18:1 trans-11 ( ), C18:1 trans-10 (ם), C18:1 cis-9 $(\mathrm{O})$, and C18:0 $(\diamond)$ concentrations ( $\mathrm{g} / 100 \mathrm{~g}$ of fatty acids) in cows fed algae concentrate (experiment 2). Values represent the means of 3 animals, with average SEM of $0.328(\downarrow), 0.543(\mathbf{\square})$, $0.864(\bigcirc)$, and $0.329(\diamond)$. 
(Glasser et al., 2007; Shingfield and Griinari, 2007). In both experiments, milk C18:0 concentrations decreased, reflecting the decreased ruminal conversion of C18:1 trans to C18:0 (Boeckaert et al., 2007a, 2008). Despite the reduced supply of $\mathrm{C} 18: 0$, concentrations of C18:1 c9 did not decrease in experiment 1 . This might relate to an increased ruminal or endogenous supply of C18:1 c9, increased $\Delta^{9}$-desaturase activity, or both. The large decrease in DMI, the fact that cows were in early lactation, or both, possibly resulted in a negative energy balance, which might have provoked an increased supply of endogenous C18:1 c9 in experiment 1, compensating for the reduced duodenal supply of C18:0. Obviously, this mechanism would not apply in experiment 2 as cows were in late lactation and DMI was not dramatically reduced. Overall, these results suggest that C18:1 c9 available for incorporation in milk triacylglycerols plays a role in the regulation of milk fatty acid synthesis upon algae feeding. Recently, Gama et al. (2008) suggested that C18:1 c9 concentrations need to exceed $8 \mathrm{~g} / 100 \mathrm{~g}$ of fatty acids to maintain milk fat fluidity. In experiment 2, C18:1 c9 concentrations reached stable values of approximately $7 \mathrm{~g} / 100 \mathrm{~g}$ of fatty acids when algae were fed, which could explain the observed milk fat depression.

\section{Milk Fatty Acid Composition}

The absence of major changes in the milk fatty acid pattern between CON and GLU or GLB in experiment 1 were not surprising because differences in the rumen environment were also lacking. Proportions of C15:0 and C17:0 in milk fat of GLU and GLB did not increase, which is an indirect indicator for unmodified amylolytic bacterial activity compared with CON (Vlaeminck et al., 2006). Algae supplementation affected the rumen biohydrogenation of $\mathrm{C} 18: 2 \mathrm{n}-6$ and $\mathrm{C} 18: 3 \mathrm{n}-3$ as reflected by the changes in milk fatty acid composition. Increased concentrations of C18:2 t11c15, CLA c9t11, CLA t9c11, C18:1 t10, and C18:1 t11 were observed in the milk fat of algae-fed cows, indicating that algae exert an inhibitory effect on the rumen biohydrogenation processes. This altered milk fatty acid profile is in agreement with previously reported responses to fish oil (Shingfield et al., 2003; Loor et al., 2005a). The shift from the production of C18:1 t11 to relatively greater production of $\mathrm{C} 18: 1 \mathrm{t} 10$ (without a $\mathrm{pH}$ decrease in the rumen) as well as CLA t9c11 production was characteristic for this study and was previously observed by Shingfield et al. (2006). In vitro studies with DHA added to rumen fluid of cows adapted to DHA showed that hydrogenation of C18:2 t11c15 was hindered and no hydrogenation of C18:1 t11 to C18:0 occurred (Vlaeminck et al., 2008). These in vitro findings help to explain the observed milk fatty acid patterns in the current in vivo trials. However, in vitro C18:1 t10 was linked to C18:1 t10 supply from the DHA-adapted rumen inoculum while its production was not induced in vitro through DHA supplementation. Temporary shifts in milk fatty acid proportions following algae supplementation in experiment 2 indicated that increasing C18:1 t10 concentrations were only partly explained by a decrease in C18:1 t11 concentrations. This is in contrast with the studies of Shingfield et al. (2006) and Roy et al. (2006) who observed that a progressive decrease over time in milk fat C18:1 t11 was associated with a concomitant increase in milk fat $\mathrm{C} 18: 1 \mathrm{t} 10$. These different responses between the current experiment and those of Shingfield et al. (2006) and Roy et al. (2006) might relate to the greater amount of sunflower oil, and hence, C18:2 n-6 in these diets.

Algae supplementation also increased milk fat DHA concentrations. The apparent transfer efficiency of DHA into milk was $5.9 \%$ when $43.0 \mathrm{~g} / \mathrm{kg}$ of DM of algae were supplemented through the rumen fistula. Likewise, algae supplementation (39.7 g of algae/kg of DM) by Franklin et al. (1999) resulted in a DHA transfer efficiency of $8.4 \%$. Recovery of DHA was $3.1 \%$ when algae were incorporated in the concentrate $(9.35 \mathrm{~g} / \mathrm{kg}$ of DMI). The low transfer efficiency of DHA from marine algae from diet to milk is in line with values reported when supplying fish oil (on average 4.1\%; Chilliard et al., 2007). This is probably related to high ruminal biohydrogenation of DHA (Fievez et al., 2007b) and the preferential incorporation of DHA into plasma phospholipids and cholesterol esters (Chilliard et al., 2007). Shingfield et al. (2006) observed a gradual decline in DHA transfer efficiency (from 5.4 to $0.8 \%$ ) when cows received a fish oil and sunflower oil supplement, which might reflect a progressive increase in the extent of ruminal DHA metabolism. Results from experiment 2 suggest no progressive increase in the extent of ruminal DHA metabolism because transfer efficiencies were constant during the last 2 wk of sampling $(3.00 \pm 0.24 \%)$. Rumen protection of DHA seems the most effective means to increase DHA in milk as DHA transfer efficiency reached $18 \%$ when $605 \mathrm{~g} / \mathrm{kg}$ DM rumen-protected tuna oil was used (Kitessa et al., 2004) and $13 \%$ when 15.3 $\mathrm{g} / \mathrm{kg}$ DM of fish oil was infused in the duodenum (Loor et al., 2005a).

\section{CONCLUSIONS}

The glucogenic diet did not induce changes in the ruminal lipid metabolism because no $\mathrm{pH}$ or SCFA concentration differences with the control diet were detected. As a result, the glucogenic diet was not successful in altering the milk fatty acid composition. Direct rumen 
supplementation of $43.0 \mathrm{~g}$ of algae $/ \mathrm{kg}$ of DM had dramatic effects on DMI and milk yield, whereas the incorporation of algae in the concentrate to reach dietary concentrations of $9.35 \mathrm{~g}$ of algae/ $\mathrm{kg}$ of DMI was not associated with these severe adverse effects on animal performance. Dietary supply of DHA-enriched micro algae resulted in an altered milk fatty acid composition toward increased concentrations of C18:2 t11c15, CLA c9t11, CLA t9c11, C18:1 trans, and DHA and decreased concentrations of SFA, in particular C18:0. A modified milk fatty acid composition upon algae feeding was associated with decreased milk fat content when algae were supplemented with the diet.

\section{ACKNOWLEDGMENTS}

C. Boeckaert has received a grant from the Institute for the Promotion of Innovation through Science and Technology in Flanders (IWT-Vlaanderen). B. Vlaeminck is a postdoctoral fellow of the Fund for Scientific Research-Flanders (Brussels, Belgium). Dries Van Hecke and Genet Mengistu are acknowledged for their technical assistance in the stables and in the lab.

\section{REFERENCES}

AbuGhazaleh, A. A., and B. N. Jacobson. 2007. The effect of $\mathrm{pH}$ and polyunsaturated $\mathrm{C} 18$ fatty acid source on the production of vaccenic acid and conjugated linoleic acids in ruminal cultures incubated with docosahexaenoic acid. Anim. Feed Sci. Technol. 136:11-22.

AbuGhazaleh, A. A., D. J. Schingoethe, A. R. Hippen, and K. F. Kalscheur. 2004. Conjugated linoleic acid increases in milk when cows fed fish meal and extruded soybeans for an extended period of time. J. Dairy Sci. 87:1758-1766.

Baer, R. J., J. Ryali, D. J. Schingoethe, K. M. Kasperson, D. C. Donovan, A. R. Hippen, and S. T. Franklin. 2001. Composition and properties of milk and butter from cows fed fish oil. J. Dairy Sci. 84:345-353.

Bauman, D. E., and J. M. Griinari. 2003. Nutritional regulation of milk fat synthesis. Annu. Rev. Nutr. 23:203-227.

Boeckaert, C., V. Fievez, D. Van Hecke, W. Verstraete, and N. Boon 2007a. Changes in rumen biohydrogenation intermediates and ciliate protozoa diversity after algae supplementation to dairy cattle. Eur. J. Lipid Sci. Technol. 109:767-777.

Boeckaert, C., B. Vlaeminck, V. Fievez, L. Maignien, J. Dijkstra, and N. Boon. 2008. Accumulation of trans C18:1 fatty acids in the rumen after dietary algae supplementation is associated with changes in the Butyrivibrio community. Appl. Environ. Microbiol. doi:10.1128/AEM.01473-08

Boeckaert, C., B. Vlaeminck, J. Mestdagh, and V. Fievez. 2007b. In vitro examination of DHA-edible micro algae 1. Effect on rumen lipolysis and biohydrogenation of linoleic and linolenic acids. Anim. Feed Sci. Technol. 136:63-79.

Chilibroste, P., S. Tamminga, J. Van Bruchem, and P. L. Van der Togt. 1998. Effect of allowed grazing time, inert rumen bulk and length of starvation before grazing on the weight, composition and fermentative end-products of the rumen contents of lactating dairy cows. Grass Forage Sci. 53:146-156.

Chilliard, Y., A. Ferlay, and M. Doreau. 2001. Dietary control of milk fat nutritional quality in the dairy cow: Trans and polyunsaturated fatty acids, and conjugated linoleic acid. Prod. Anim. 14:323335.
Chilliard, Y., F. Glasser, A. Ferlay, L. Bernard, J. Rouel, and M. Doreau. 2007. Diet, rumen biohydrogenation and nutritional quality of cow and goat milk fat. Eur. J. Lipid Sci. Technol. 109:828-855.

Chow, T. T., V. Fievez, A. P. Moloney, K. Raes, D. Demeyer, and S. De Smet. 2004. Effect of fish oil on in vitro rumen lipolysis, apparent biohydrogenation of linoleic and linolenic acid and accumulation of biohydrogenation intermediates. Anim. Feed Sci. Technol. 117:1-12.

CVB. 2005. Veevoedertabel 2004-2005. Centraal Veevoederbureau, Lelystad, the Netherlands.

Donovan, D. C., D. J. Schingoethe, R. J. Baer, J. Ryali, A. R. Hippen, and S. T. Franklin. 2000. Influence of dietary fish oil on conjugated linoleic acid and other fatty acids in milk fat from lactating dairy cows. J. Dairy Sci. 83:2620-2628.

European Community. 1993. Determination of Crude Protein. Directive no. L179/9 of the Commission of the European Communities of 22.07.93. Off. J. European Community, Brussels, Belgium.

Fievez, V., C. Boeckaert, B. Vlaeminck, J. Mestdagh, and D. Demeyer. 2007a. In vitro examination of DHA-edible micro-algae 2. Effect on rumen methane production and apparent degradability of hay. Anim. Feed Sci. Technol. 136:80-95.

Fievez, V., B. Vlaeminck, T. Jenkins, F. Enjalbert, and M. Doreau. 2007b. Assessing rumen biohydrogenation and its manipulation in vivo, in vitro and in situ. Eur. J. Lipid Sci. Technol. 109:740756.

Folch, J., M. Lees, and S. G. H. Sloane Stanley. 1957. A simple method for the isolation and purification of total lipids from animal tissues. J. Biol. Chem. 226:497-509.

Franklin, S. T., K. R. Martin, R. J. Baer, D. J. Schingoethe, and A. R. Hippen. 1999. Dietary marine algae (Schizochytrium sp.) increases concentrations of conjugated linoleic, docosahexaenoic and transvaccenic acids in milk of dairy cows. J. Nutr. 129:20482054 .

Gama, M. A. S., P. C. Garnsworthy, J. M. Griinari, P. R. Leme, P. H. M. Rodrigues, L. W. O. Souza, and D. P. D. Lanna. 2008. Diet-induced milk fat depression: Association with changes in milk fatty acid composition and fluidity of milk fat. Livest. Sci. 115:319-331

Glasser, F., M. Doreau, A. Ferlay, J. J. Loor, and Y. Chilliard. 2007. Milk fatty acids: Mammary synthesis could limit transfer from duodenum in cows. Eur. J. Lipid Sci. Technol. 109:817-827.

International Dairy Federation (IDF). 1987. Determination of fat content-Röse-Gottlieb gravimetric method. IDF, Brussels, Belgium.

International Organization for Standardization (ISO). 1973. ISO-1443: The Soxhlet method. ISO, Geneva, Switzerland.

International Organization for Standardization (ISO). 1999. ISO9622: Whole milk - Determination of milk fat, protein and lactose content-Guidance on the operation of mid-infrared instruments. ISO, Geneva, Switzerland.

Jenkins, T. C. 1993. Lipid metabolism in the rumen. J. Dairy Sci 76:3851-3863.

Kalscheur, K. F., B. B. Teter, L. S. Piperova, and R. A. Erdman. 1997. Effect of dietary forage concentration and buffer addition on duodenal flow of trans-C-18:1 fatty acids and milk fat production in dairy cows. J. Dairy Sci. 80:2104-2114.

Keady, T. W. J., and C. S. Mayne. 1999. The effects of level of fish oil inclusion in the diet on rumen digestion and fermentation parameters in cattle offered grass silage based diets. Anim. Feed Sci. Technol. 81:57-68.

Kitessa, S. M., S. K. Gulati, G. C. Simos, J. R. Ashes, T. W. Scott, E. Fleck, and P. C. Wynn. 2004. Supplementation of grazing dairy cows with rumen-protected tuna oil enriches milk fat with n-3 fatty acids without affecting milk production or sensory characteristics. Br. J. Nutr. 91:271-277.

Lock, A. L., C. Tyburczy, D. A. Dwyer, K. J. Harvatine, F. Destaillats, Z. Mouloungui, L. Candy, and D. E. Bauman. 2007. Trans-10 octadecenoic acid does not reduce milk fat synthesis in dairy cows. J. Nutr. 137:71-76. 
Loor, J. J., M. Doreau, J. M. Chardigny, A. Ollier, J. L. Sebedio, and Y. Chilliard. 2005a. Effects of ruminal or duodenal supply of fish oil on milk fat secretion and profiles of trans- fatty acids and conjugated linoleic acid isomers in dairy cows fed maize silage. Anim. Feed Sci. Technol. 119:227-246.

Loor, J. J., A. Ferlay, A. Ollier, K. Ueda, M. Doreau, and Y. Chilliard. 2005b. High- concentrate diets and polyunsaturated oils alter trans and conjugated isomers in bovine rumen, blood, and milk. J. Dairy Sci. 88:3986-3999.

Lourenço, M., S. De Smet, K. Raes, and V. Fievez. 2007. Effect of botanical composition of silages on rumen fatty acid metabolism and fatty acid composition in longissimus muscle and subcutaneous fat of lambs. Animal 1:911-921.

Martin, C., L. Brossard, and M. Doreau. 2006. Mechanisms of appearance of ruminal acidosis and consequences on physiopathology and performances. Prod. Anim. 19:93-107.

Palmquist, D. L., and J. M. Griinari. 2006. Milk fatty acid composition in response to reciprocal combinations of sunflower and fish oils in the diet. Anim. Feed Sci. Technol. 131:358-369.

Precht, D., and J. Molkentin. 2000. Identification and quantitation of cis/trans C16:1 and C17:1 fatty acid positional isomers in German human milk lipids by thin-layer chromatography and gas chromatography/mass spectrometry. Eur. J. Lipid Sci. Technol. 102:102-113.

Raes, K., S. de Smet, and D. Demeyer. 2001. Effect of doublemuscling in Belgian Blue young bulls on the intramuscular fatty acid composition with emphasis on conjugated linoleic acid and polyunsaturated fatty acids. Anim. Sci. 73:253-260.

Ratnayake, W. M. N. 1998. Analysis of trans fatty acids. Pages 115161 in Trans Fatty Acids in Human Nutrition, Vol. 9. J. L. Sébédio and W. W. Christie, ed. The Oily Press, Dundee, UK.

Roy, A., A. Ferlay, K. J. Shingfield, and Y. Chilliard. 2006. Examination of the persistency of milk fatty acid composition responses to plant oils in cows given different basal diets, with particular emphasis on trans-C-18:1 fatty acids and isomers of conjugated linoleic acid. Anim. Sci. 82:479-492.

SAS Institute. 2004. User's Guide: Statistics. SAS 9.1.SAS Institute Inc., Cary, NC.
Shingfield, K. J., S. Ahvenjarvi, V. Toivonen, A. Arola, K. V. V. Nurmela, P. Huhtanen, and J. M. Griinari. 2003. Effect of dietary fish oil on biohydrogenation of fatty acids and milk fatty acid content in cows. Anim. Sci. 77:165-179.

Shingfield, K. J., and J. M. Griinari. 2007. Role of biohydrogenation intermediates in milk fat depression. Eur. J. Lipid Sci. Technol. 109:799-816.

Shingfield, K. J., C. K. Reynolds, G. Hervás, J. M. Griinari, A. S. Grandison, and D. E. Beever. 2006. Examination of the persistency of milk fatty acid composition responses to fish oil and sunflower oil in the diet of dairy cows. J. Dairy Sci. 89:714-732.

Tamminga, S., W. M. Vanstraalen, A. P. J. Subnel, R. G. M. Meijer, A. Steg, C. J. G. Wever, and M. C. Blok. 1994. The Dutch protein evaluation system-The DVE/OEB system. Livest. Prod. Sci. 40:139-155.

Van Es, A. J. H. 1978. Feed evaluation for ruminants. 1. Systems in use from May 1977 onwards in Netherlands. Livest. Prod. Sci. $5: 331-345$.

Van Nevel, C. J., and D. I. Demeyer. 1977. Effect of monensin on rumen metabolism in vitro. Appl. Environ. Microbiol. 34:251-257.

Van Nevel, C. J., and D. I. Demeyer. 1996. Influence of $\mathrm{pH}$ on lipolysis and biohydrogenation of soybean oil by rumen contents in vitro. Reprod. Nutr. Dev. 36:53-63.

Van Soest, P. J., J. B. Robertson, and B. A. Lewis. 1991. Methods for dietary fiber, neutral detergent fiber and nonstarch polysaccharides in relation to animal nutrition. J. Dairy Sci. 88:1031-1041.

Vlaeminck, B., C. Dufour, A. M. van Vuuren, A. R. J. Cabrita, R. J. Dewhurst, D. Demeyer, and V. Fievez. 2005. Use of odd and branched-chain fatty acids in rumen contents and milk as a potential microbial marker. J. Dairy Sci. 88:1031-1042.

Vlaeminck, B., V. Fievez, A. R. J. Cabrita, A. J. M. Fonseca, and R J. Dewhurst. 2006. Factors affecting odd and branched-chain fatty acids in milk: A review. Anim. Feed Sci. Technol. 131:389-417.

Vlaeminck, B., G. Mengistu, V. Fievez, L. de Jonge, and J. Dijkstra. 2008. Effect of in vitro docosahexaenoic acid supplementation to marine algae-adapted and unadapted rumen inoculum on the biohydrogenation of unsaturated fatty acids in freeze dried grass. J. Dairy Sci. 91:1122-1132. 